\title{
Novel synthetic inhibitors of 3-hydroxy-3-methylglutaryl- coenzyme A (HMG-CoA) reductase activity that inhibit tumor cell proliferation and are structurally unrelated to existing statins
}

\author{
JEAN-PIERRE H. PERCHELLET ${ }^{1}$, ELISABETH M. PERCHELLET ${ }^{2}$, KYLE R. CROW $^{1}$, \\ KEITH R. BUSZEK ${ }^{2,3}$, NEIL BROWN ${ }^{2,3}$, SAMPATHKUMAR ELLAPPAN ${ }^{2}$, GE GAO $^{2}$, \\ DIHENG LUO $^{2}$, MACHIKO MINATOYA ${ }^{2}$ and GERALD H. LUSHINGTON ${ }^{3,4}$
}

\author{
${ }^{1}$ Anti-Cancer Drug Laboratory, Kansas State University, Division of Biology, Ackert Hall, Manhattan, \\ KS 66506-4901; ${ }^{2}$ Department of Chemistry, University of Missouri-Kansas City, 205 Spencer Chemical Laboratories, \\ 5100 Rockhill Road, Kansas City, MO 64110-2481; ${ }^{3}$ University of Kansas, Center of Excellence in Chemical \\ Methodologies and Library Development, Structural Biology Center, 2121 Simons Drive, Lawrence, \\ KS 66047; ${ }^{4}$ Department of Medicinal Chemistry, University of Kansas, Molecular Graphics \\ and Modeling Laboratory, 1251 Wescoe Hall Drive, Lawrence, KS 66045-7582, USA
}

Received July 27, 2009; Accepted August 24, 2009

DOI: 10.3892/ijmm_00000274

\begin{abstract}
Pilot-scale libraries of eight-membered medium ring lactams (MRLs) and related tricyclic compounds (either seven-membered lactams, thiolactams or amines) were screened for their ability to inhibit the catalytic activity of human recombinant 3-hydroxy-3-methylglutaryl-coenzyme A (HMG-CoA) reductase in vitro. A dozen of the synthetic compounds mimic the inhibition of purified HMG-CoA reductase activity caused by pravastatin, fluvastatin and sodium salts of lovastatin, mevastatin and simvastatin in this cell-free assay, suggesting direct interaction with the ratelimiting enzyme of cholesterol biosynthesis. Moreover, several MRLs inhibit the metabolic activity of L1210 tumor cells in vitro to a greater degree than fluvastatin, lovastatin, mevastatin and simvastatin, whereas pravastatin is inactive. Although the correlation between the concentrationdependent inhibitions of HMG-CoA reductase activity over $10 \mathrm{~min}$ in the cell-free assay and L1210 tumor cell proliferation over 4 days in culture is unclear, some bioactive MRLs elicit interesting combinations of statin-like $\left(\mathrm{IC}_{50}: 7.4-8.0 \mu \mathrm{M}\right)$ and anti-tumor $\left(\mathrm{IC}_{50}: 1.4-2.3 \mu \mathrm{M}\right)$ activities. The HMG-CoA reductase-inhibiting activities of pravastatin and an MRL persist in the presence of increasing concentrations of NADPH. But increasing concentrations of HMG-CoA block the HMG-CoA reductase-inhibiting activity of pravastatin
\end{abstract}

Correspondence to: Dr Jean-Pierre Perchellet, Anti-Cancer Drug Laboratory, Kansas State University, Division of Biology, Ackert Hall, Manhattan, KS 66506-4901, USA

E-mail: jpperch@ksu.edu

Key words: synthetic medium ring lactams, HMG-CoA reductase activity, statin drugs, tumor cell proliferation without altering that of an MRL, suggesting that MRLs and existing statins may have different mechanisms of enzyme interaction and inhibition. When tested together, suboptimal concentrations of synthetic MRLs and existing statins have additive inhibitory effects on HMG-CoA reductase activity. Preliminary molecular docking studies with MRL-based inhibitors indicate that these ligands fit sterically well into the HMG-CoA reductase statin-binding receptor model and, in contrast to mevastatin, may occupy a narrow channel housing the pyridinium moiety on $\mathrm{NADP}^{+}$.

\section{Introduction}

Eight-membered and medium-ring lactones are rare and their therapeutic properties largely unknown (1-4). A synthetic analog of the natural marine product, octalactin A (1), was previously shown to inhibit L1210 tumor cell proliferation without altering the rates of DNA, RNA and protein syntheses (2). But this compound inhibited the polymerization of purified tubulin, suggesting that microtubule de-stabilization might be involved in its cytostatic action (2). Pilot-scale libraries of 2nd and 3rd generation 8-membered medium-ring lactams (MRLs) inspired by octalactin A were then synthesized for optimization studies and screened for bioactivity in hyperplastic tumor cell systems in vitro $(3,4)$. Several MRLs inhibited, in a concentration- and time-dependent manner, tumor cell proliferation in the low $\mu \mathrm{M}$ range after 2 and 4 days in culture and were effective across a spectrum of leukemic (L1210 and HL-60), pancreatic (Pan02) and mammary (SK-BR-3) tumor cell lines. Novel MRLs containing series of amino acid derivatives inhibited the metabolic activity of tumor cells in the $\mathrm{nM}$ range after 2-4 days and blocked the incorporations of ${ }^{3} \mathrm{H}$-thymidine into DNA, ${ }^{3} \mathrm{H}$ uridine into RNA and ${ }^{3} \mathrm{H}$-leucine into protein used to assess the rates of macromolecule syntheses in L1210 tumor cells after 1.5-3 $\mathrm{h}$. 
When tested for their DNA-binding affinity, however, antiproliferative MRLs did not induce a loss of ethidium bromide (EB) fluorescence, suggesting that these compounds did not directly interact with double-stranded DNA to disrupt its structural and functional integrity and prevent EB from intercalating into DNA base pairs. As compared to microtubuledisrupting agents, antiproliferative MRLs very weakly increased the mitotic index of L1210 tumor cells at $24 \mathrm{~h}$ but stimulated the formation of many binucleated cells and a few micronuclei, suggesting that MRLs might enhance mitotic abnormality, induce chromosomal damage or missegregation, and block cytokinesis. Interestingly, certain MRL structures were recently discovered to directly inhibit the catalytic activity of human 3-hydroxy-3-methylglutaryl-coenzyme A (HMG-CoA) reductase in a cell-free assay in vitro, suggesting that these novel small molecules might elicit both antitumor and statin-like activities. The present study was undertaken to determine the combined HMG-CoA reductase-inhibiting and antiproliferative activities of these unique MRL structures, which occupy a region of chemical-space diversity that few bioactive compounds populate and are structurally unrelated to existing statin drugs.

\section{Materials and methods}

Compound synthesis. The synthesis of the 10-member sublibrary of novel unsaturated eight-membered lactam compounds used in this study (DL-II-D4 and DL-II-D7; GG-II-Ala29,
GG-II-G3-cis, and GG-II-G7; NB-IX-Gly27, NB-IX-Gly35, NB-IX-Gly38, NB-IX-Gly44 and NB-IX-Gly46) was performed in the convergent-divergent manner described previously $(3,4)$. In general, ring-closing metathesis (RCM) of a collection of diene amides (prepared from the carboxylic acids and the fluorinated secondary allyl amine), was followed, after deprotection, by parallel derivatization of the resulting cyclic secondary amine scaffold (Scheme 1). This process afforded a series of amines (NB-IX-Gly27), amides (GG-IIG3 and GG-II-G7), carbamates (NB-IX-Gly44 and NB-IXGly46), sulfonamides (DL-II-D4, DL-II-D7, GG-II-Ala29, NB-IX-Gly35, and NB-IX-Gly38), and ureas (none in the present study). Mixtures of diastereomeric derivatized lactams were used in the present study with the exception of amide GG-II-G3, which was prepared as the optically active, diastereomerically pure cis isomer. The required amides were themselves prepared from the naturally occurring and optically pure amino acids glycine, L-alanine, and L-phenylalanine.

The synthesis of two of the most potent members of a new class of tricyclic seven-membered lactam (SE-III-468 and SE-III-525) was carried out using the aryne cycloaddition strategies developed in the Buszek laboratories (Scheme 2) (5-9). In this manner, a collection of tertiary diene amides (prepared in four steps from Danheiser's aldehyde) (10) was subjected to fluoride-induced decomposition of a tethered o-silyltriflate moiety to give the benzyne, which then underwent a facile intramolecular cycloaddition to afford directly the desired compounds.

\section{Scheme 1}

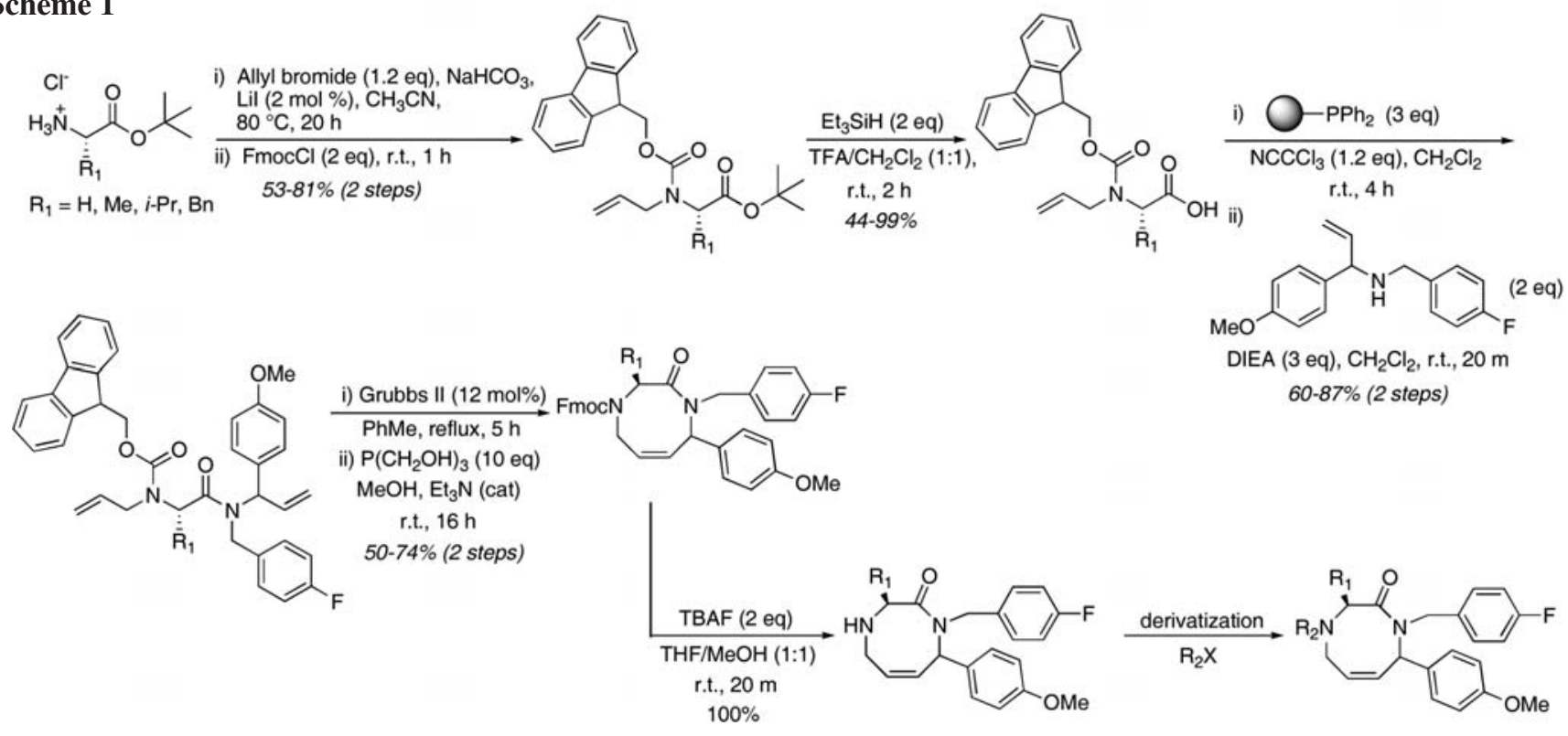

Scheme 2

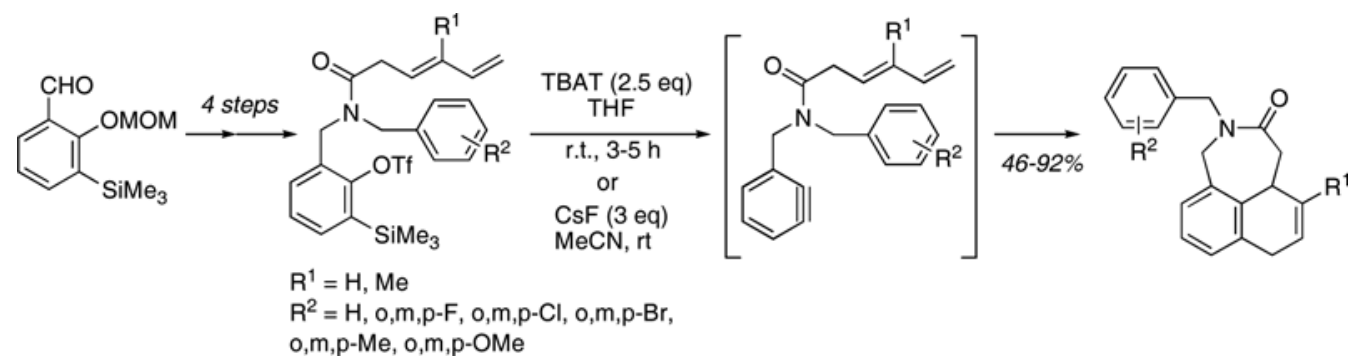


HMG-CoA reductase activity. The HMG-CoA reductase assay kit from Sigma-Aldrich (St. Louis, MO, USA) with the catalytic domain of the human enzyme (recombinant GST fusion protein expressed in E. coli) was used, under conditions recommended by the manufacturer, to rapidly screen pilotscale libraries of novel MRLs and related derivatives and identify the most effective lead bioactive compounds with statin-like activities. The concentration of the purified human enzyme stock solution (Sigma) was $0.52-0.85 \mathrm{mg}$ protein $/ \mathrm{ml}$. Reference statin drugs, including lovastatin, mevastatin, simvastatin (all from Sigma) and sodium salts of fluvastatin (from Alexis Biochemicals, San Diego, CA, USA), pravastatin (from Sigma), lovastatin, mevastatin and simvastatin (all from Calbiochem, EMD Chemicals Inc., La Jolla, CA, USA), were used as positive controls. To characterize HMG-CoA reductase inhibition under defined assay conditions, reactions, containing $4 \mu \mathrm{l}$ of NADPH (to obtain a final concentration of $400 \mu \mathrm{M}$ ) and $12 \mu \mathrm{l}$ of HMG-CoA substrate (to obtain a final concentration of $400 \mu \mathrm{M}$ ) in a final volume of $0.2 \mathrm{ml}$ of $100 \mathrm{mM}$ potassium phosphate buffer, $\mathrm{pH} \mathrm{7.4,}$ containing $120 \mathrm{mM} \mathrm{KCl}, 1 \mathrm{mM}$ EDTA and $5 \mathrm{mM}$ DTT, were initiated (time 0 ) by the addition of $2 \mu \mathrm{l}$ of the catalytic domain of human recombinant HMG-CoA reductase and incubated in quartz microcells at $37^{\circ} \mathrm{C}$ in the presence or absence (control) of $1-\mu 1$ aliquots of drugs dissolved in dimethyl sulfoxide (DMSO). The rates of NADPH consumed were monitored every $20 \mathrm{sec}$ for up to 300-720 sec by scanning spectrophotometrically the decrease in absorbance at $340 \mathrm{~nm}$, using a Shimadzu UV-160 spectrophotometer equipped with double-beam optics and a thermostatically controlled cell holder. Results were expressed as \% of the control specific activity of the enzyme ( $\mu \mathrm{mol}$ of NADPH oxidized $/ \mathrm{min} / \mathrm{mg}$ protein) in the absence of drugs.

Cell culture and proliferation assay. Suspension cultures of murine L1210 lymphocytic leukemia cells (ATCC, Manassas, VA) were incubated at $37^{\circ} \mathrm{C}$ in a humidified atmosphere containing $5 \% \mathrm{CO}_{2}$ and maintained in continuous exponential growth by twice-a-week passage in RPMI-1640 medium supplemented with $10 \%$ fetal bovine calf serum (Atlanta Biologicals, Norcross, GA) and penicillin (100 IU/ml)streptomycin $(100 \mu \mathrm{g} / \mathrm{ml})$. L1210 cell suspensions were grown in triplicate in 48-well Costar cell culture plates for 4 days in the presence or absence (control) of serial concentrations of synthetic MRLs or reference statin drugs, dissolved and diluted in DMSO, to evaluate their antiproliferative activity. Since compounds were supplemented to the culture medium in $1-\mu 1$ aliquots, the concentrations of vehicle in the final incubation volume $(0.5 \mathrm{ml})$ never exceeded $0.2 \%$ and did not interfere with the data. The proliferation of drug-treated L1210 tumor cells (initial density $4.7 \times 10^{3} / 0.5 \mathrm{ml} /$ well) was assessed from their mitochondrial ability to bioreduce the 3(4,5-dimethyl-thiazol-2-yl)-5-(3-carboxymethoxyphenyl)-2(4-sulfophenyl)-2H-tetrazolium (MTS) reagent (Promega, Madison, WI) in the presence of phenazine methosulfate (PMS; Sigma) into a water-soluble formazan product that absorbs at $490 \mathrm{~nm}$ (11). After 4 days in culture, control and drug-treated L1210 cell samples (about 10\% $/ 0.5 \mathrm{ml} /$ well for controls) were further incubated at $37^{\circ} \mathrm{C}$ for $2 \mathrm{~h}$ in the dark in the presence of $0.1 \mathrm{ml}$ of MTS:PMS (2:0.1) reagent and their relative metabolic activity was estimated by recording the absorbance at $490 \mathrm{~nm}$, using a Cambridge model 750 automatic microplate reader (Packard, Downers Grove, IL). Blank values for culture medium supplemented with MTS:PMS reagent in the absence of cells were substracted from the results. Data were analyzed using Student's t-test with a level of significance set at $\mathrm{P}<0.05$.

Computational docking. Molecular docking was performed to assess and compare the pharmacophore associated with our HMG-CoA reductase-inhibiting MRLs and other known statins. As receptor model, we chose the species with a cocrystallized inhibitor with the greatest similarity to compound DL-II-D4: structure 3BGL (PDB code) with a bound sulfamoyl pyrrole species whose Tanimoto similarity to DLII-D4 was 0.45 as computed based on UNITY fingerprints $(12,13)$. For docking, the receptor was defined as all amino acid residues within the 3BGL structure, devoid of any crystallographic waters, ions or the bound ligand. The receptor model was then protonated in SYBYL (14) assuming physiological pH (i.e., anionic aspartate and glutamate species, and cationic arginines and lysines). To define the range of inhibitor interactions available to bound ligand, a protomol file was constructed based on a chemically diverse set of cocrystallized HMG-CoA reductase inhibitors as resolved in the crystal structures 1HWL (15), 1DQ9 (16), 3CD5 (17), and $3 \mathrm{CCZ}$ (17). The complete protein-ligand complexes were mutually aligned in SYBYL (14) according to minimized $\mathrm{C} \alpha$ root-mean-squared positional deviations. All ligands were then extracted and merged into a single molecule file, which was subjected to protomol-generation via Surflex (18) using default settings for perception of donor, acceptor and hydrophobic features. Co-crystallized inhibitors from the structures 3BGL, 1HWL, 1DQ9, 3CD5 and 3CCZ were then docked into the HMG-CoA reductase receptor model via Surflex using default settings and the protomol file defined above. This led to very close structural agreement relative to the experimentally resolved ligand atomic positions (average RMSD of $0.4 \AA$ ).

\section{Results}

Inhibition of HMG-CoA reductase activity. Pilot-scale libraries totaling 131 eight- or nine-membered MRLs and related tricyclic compounds (either seven-membered lactams, thiolactams or amines) were screened for their ability to inhibit the catalytic activity of human recombinant HMGCoA reductase in vitro. The chemical syntheses and structures of most of these novel compounds have already been published or will be reported in detail elsewhere $(3,4)$. This study was initiated after we discovered that spectrophotometric time scans demonstrated the ability of $4-25 \mu \mathrm{M}$ concentrations of DL-II-D7 to increasingly mimic the inhibitory activity of 41-256 $\mathrm{nM}$ concentrations of pravastatin on the catalytic domain of purified HMG-CoA reductase in a cell-free assay in vitro (Fig. 1), suggesting direct interaction with the rate-limiting enzyme of cholesterol biosynthesis. Because the inhibitory effects of DL-II-D7 appeared to be $1 / 2$ maximal around $10 \mu \mathrm{M}$ (Fig. 1), this concentration was used to screen several pilot-scale libraries of synthetic MRLs or related compounds to identify novel HMG-CoA reductase 


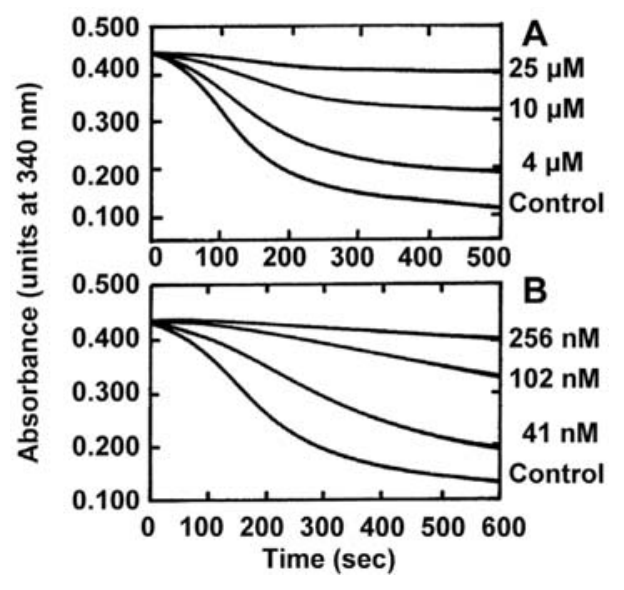

Figure 1. Spectrophotometric time-scans demonstrating the ability of DL-IID7 (A) to mimic the HMG-CoA reductase-inhibiting activity of pravastatin (B), using the HMG-CoA reductase screening assay kit from Sigma-Aldrich in vitro. Reactions, containing $4 \mu 1$ of NADPH and $12 \mu 1$ of HMG-CoA substrate in a final volume of $0.2 \mathrm{ml}$ of assay buffer, were initiated (time 0 ) by the addition of $2 \mu \mathrm{l}$ of the catalytic domain of human recombinant HMG$\mathrm{CoA}$ reductase and incubated in quartz microcells at $37^{\circ} \mathrm{C}$ in the presence or absence (control) of 1- $\mu 1$ aliquots of drugs dissolved in DMSO. The rates of NADPH consumed were monitored every $20 \mathrm{sec}$ for up to $500-600 \mathrm{sec}$ by scanning the decreases in absorbance at $340 \mathrm{~nm}$. (A) The concentration of the enzyme stock solution was $0.85 \mathrm{mg}$ protein $/ \mathrm{ml}$ and the specific activity of the control reaction calculated between $20-300 \mathrm{sec}$ was $0.555268 \mu \mathrm{mol}$ of NADPH oxidized/min/mg protein. (B) The concentration of the enzyme stock solution was $0.6 \mathrm{mg}$ protein/ $\mathrm{ml}$ and the specific activity of the control reaction calculated between $0-340 \mathrm{sec}$ was $0.583976 \mu \mathrm{mol}$ of NADPH oxidized $/ \mathrm{min} / \mathrm{mg}$ protein.

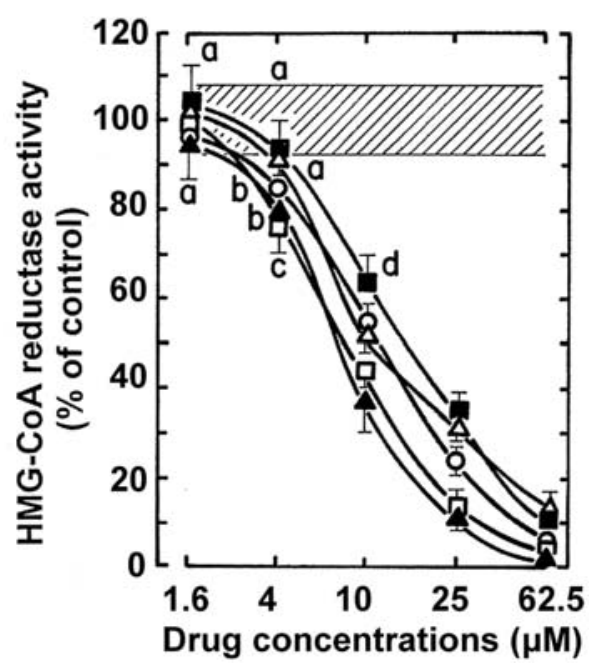

Figure 2. Comparison of the abilities of serial concentrations (plotted on a logarithmic scale) of GG-II-Ala29 (०), GG-II-G3 ( $\square$ ), GG-II-G7 ( $\Delta$ ), DL-II-

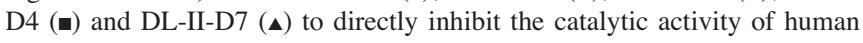
HMG-CoA reductase in a cell-free assay in vitro. The concentration of the HMG-CoA reductase stock solution was $0.6 \mathrm{mg}$ protein $/ \mathrm{ml}$. Reactions were incubated at $37^{\circ} \mathrm{C}$ in quartz microcells and the rates of NADPH consumed were calculated from the decreases in spectrophotometric absorbance at $340 \mathrm{~nm}$ between 20 and $300 \mathrm{sec}$ after addition of the enzyme. Results are expressed as $\%$ of the control specific activity of the enzyme in the absence of drugs $(0.564405 \pm 0.044024 \mu$ mole of NADPH oxidized $/ \mathrm{min} / \mathrm{mg}$ protein, $100 \pm 7.8 \%$, striped area). Bars, means \pm SD $(n=3)$. ${ }^{a}$ Not different from control; ${ }^{\mathrm{b}} \mathrm{P}<0.05,{ }^{\mathrm{c}} \mathrm{P}<0.025$ and ${ }^{\mathrm{d}} \mathrm{P}<0.005$, smaller than control.

inhibitors. None of the first 16 eight-membered MRLs, synthesized for optimization studies and previously tested for their

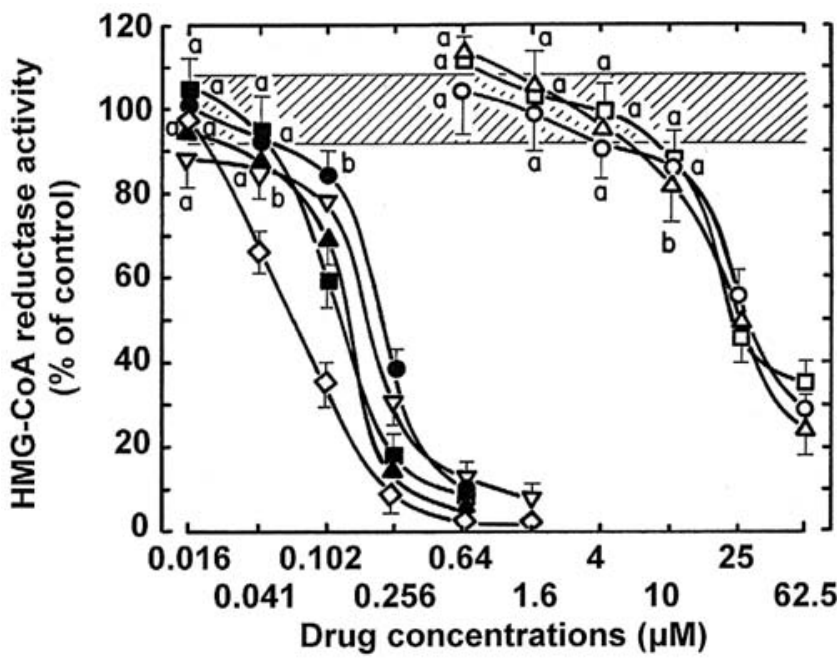

Figure 3. Comparison of the abilities of serial concentrations (logarithmic scale) of pravastatin $(\diamond)$, fluvastatin $(\nabla)$, lovastatin $(\diamond)$, mevastatin $(\square)$, simvastatin $(\Delta)$ and sodium salts of lovastatin (•), mevastatin ( $\bullet$ ) and simvastatin ( $\mathbf{\Lambda})$ to directly inhibit the catalytic activity of human HMG-CoA reductase in a cell-free assay in vitro. The concentration of the HMG-CoA reductase stock solution was $0.85 \mathrm{mg}$ protein $/ \mathrm{ml}$. Reactions were incubated at $37^{\circ} \mathrm{C}$ in quartz microcells and the rates of NADPH consumed were calculated from the decreases in spectrophotometric absorbance at $340 \mathrm{~nm}$ between 20 and $340 \mathrm{sec}$ after addition of the enzyme. Results are expressed as \% of the control specific activity of the enzyme in the absence of drugs $(0.529439 \pm 0.043084 \mu$ mole of NADPH oxidized $/ \mathrm{min} / \mathrm{mg}$ protein, $100 \pm 8.1 \%$, striped area). Bars, means $\pm \mathrm{SD}(\mathrm{n}=3)$. ${ }^{\mathrm{a}}$ Not different from control; ${ }^{\mathrm{b}} \mathrm{P}<0.05$, smaller than control.

antiproliferative activity, had any significant effect at $10 \mu \mathrm{M}$ in the HMG-CoA reductase activity assay. In contrast, 16 of the next 64 compounds, representing a 3rd generation of eight-membered MRLs, significantly inhibited the specific activity of purified HMG-CoA reductase when compared at $10 \mu \mathrm{M}$. Finally, a single of the last 51 compounds, representing nine-membered MRLs and other related tricyclic structures, was able to significantly inhibit HMG-CoA reductase activity in the screening assay at $10 \mu \mathrm{M}$. Only the best 10 of those 17 novel HMG-CoA reductase-inhibiting compounds are shown in this study, the structures of the most effective lead compounds with statin-like activity being DL-II-D7, GG-IIG3, GG-II-G7, GG-II-Ala29 and DL-II-D4 (Fig. 2). Based on full concentration-response curves, the $\mathrm{IC}_{50}$ values for the inhibition of HMG-CoA reductase activity by DL-II-D4, GGII-Ala29, GG-II-G7, GG-II-G3 and DL-II-D7 are 14.4 \pm 0.9 , $11.5 \pm 0.7,10.3 \pm 0.5,8.0 \pm 0.6$ and $7.4 \pm 1.1 \mu \mathrm{M}$, respectively (Fig. 2). But under similar experimental conditions in the HMG-CoA reductase activity assay, the $\mathrm{IC}_{50}$ values of known HMG-CoA reductase inhibitors are: pravastatin, $66.1 \mathrm{nM}$; fluvastatin, $172.8 \mathrm{nM}$; mevastatin (sodium salt), $119.2 \mathrm{nM}$; simvastatin (sodium salt), $134.0 \mathrm{nM}$; and lovastatin (sodium salt), $210.9 \mathrm{nM}$ (Fig. 3). Mevastatin, simvastatin and lovastatin, which require activation by cellular enzymes, are much less effective against HMG-CoA reductase in this cell-free assay $\left(\mathrm{IC}_{50}\right.$ values: 22.5, 25.4 and $27.7 \mu \mathrm{M}$, respectively) (Fig. 3).

The HMG-CoA reductase-inhibiting activities of pravastatin and DL-II-D7 similarly persist in the presence of increasing concentrations of NADPH (data not shown). But increasing 400-6,400 $\mu \mathrm{M}$ concentrations of HMG-CoA 


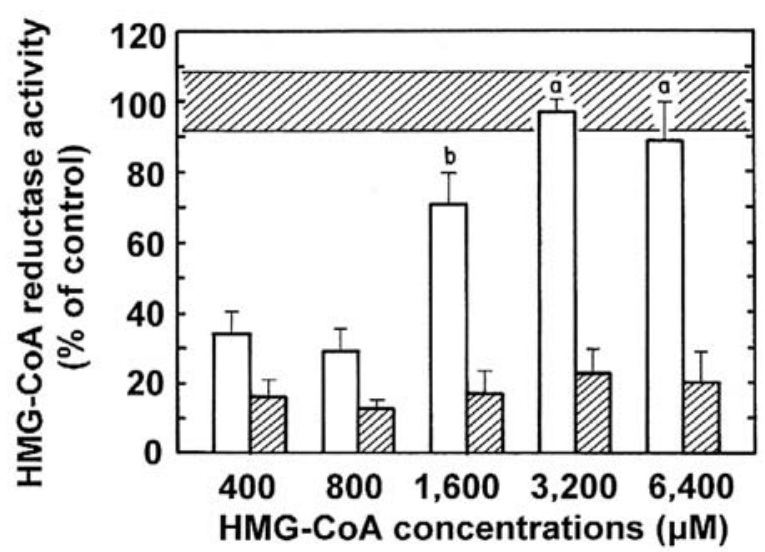

Figure 4. Comparison of the abilities of $25 \mu \mathrm{M}$ DL-II-D7 (striped columns) and $256 \mathrm{nM}$ pravastatin (open columns) to directly inhibit the catalytic activity of human HMG-CoA reductase in the presence of increasing concentrations of HMG-CoA substrate in a cell-free assay in vitro. Reactions, containing $4 \mu \mathrm{l}$ of NADPH (to obtain a fixed final concentration of $400 \mu \mathrm{M}$ ) and $12 \mu 1$ of HMG-CoA substrate (to obtain variable final concentrations of 400-6,400 $\mu \mathrm{M}$ ) in a final volume of $0.2 \mathrm{ml}$ of assay buffer, were initiated (time 0 ) by the addition of $2 \mu 1$ of the catalytic domain of human recombinant $\mathrm{HMG}-\mathrm{CoA}$ reductase and incubated in quartz microcells at $37^{\circ} \mathrm{C}$ in the presence or absence (control) of $1-\mu 1$ aliquots of drugs dissolved in DMSO. The concentration of the HMG-CoA reductase stock solution was $0.52 \mathrm{mg}$ protein $/ \mathrm{ml}$. The rates of NADPH consumed were calculated from the decreases in spectrophotometric absorbance at $340 \mathrm{~nm}$ between 20 and $620 \mathrm{sec}$ after addition of the enzyme. Results are expressed as $\%$ of the respective control specific activities of the enzyme in the absence of drugs $(100 \pm 8.2 \%$, striped area). The control specific activity of HMG-CoA reductase in the presence of $400 \mu \mathrm{M}$ HMG-CoA substrate was $0.487231 \pm 0.040148 \mu$ mole of NADPH oxidized $/ \mathrm{min} / \mathrm{mg}$ protein. Bars, means \pm SD $(n=3)$. ${ }^{\text {Not }}$ different from control; ${ }^{b} \mathrm{P}<0.05$, smaller than control.

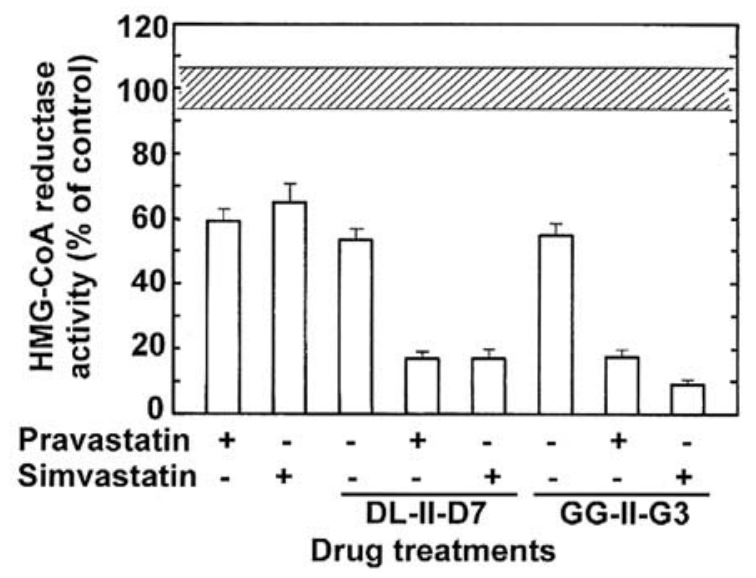

Figure 5. Comparison of the abilities of single or combined treatments with $64 \mathrm{nM}$ pravastatin or simvastatin (sodium salt) and $10 \mu \mathrm{M}$ DL-II-D7 or GGII-G3 to directly inhibit the catalytic activity of human HMG-CoA reductase in a cell-free assay in vitro. Reactions, containing $4 \mu 1$ of NADPH (to obtain a final concentration of $400 \mu \mathrm{M}$ ) and $12 \mu 1$ of HMG-CoA substrate (to obtain a final concentration of $400 \mu \mathrm{M}$ ) in a final volume of $0.2 \mathrm{ml}$ of assay buffer, were initiated (time 0 ) by the addition of $2 \mu 1$ of the catalytic domain of human recombinant $\mathrm{HMG}-\mathrm{CoA}$ reductase and incubated in quartz microcells at $37^{\circ} \mathrm{C}$ in the presence or absence (control) of $1-\mu 1$ aliquots of drugs dissolved in DMSO. The concentration of the HMG-CoA reductase stock solution was $0.52 \mathrm{mg}$ protein $/ \mathrm{ml}$. The rates of NADPH consumed were calculated from the decreases in spectrophotometric absorbance at $340 \mathrm{~nm}$ between 0 and $720 \mathrm{sec}$ after addition of the enzyme. Results are expressed as \% of the control specific activity of the enzyme in the absence of drugs $(0.384534 \pm 0.023841 \mu \mathrm{mol}$ of NADPH oxidized $/ \mathrm{min} / \mathrm{mg}$ protein, $100 \pm 6.2 \%$, striped area). Bars, means \pm SD $(n=3)$.
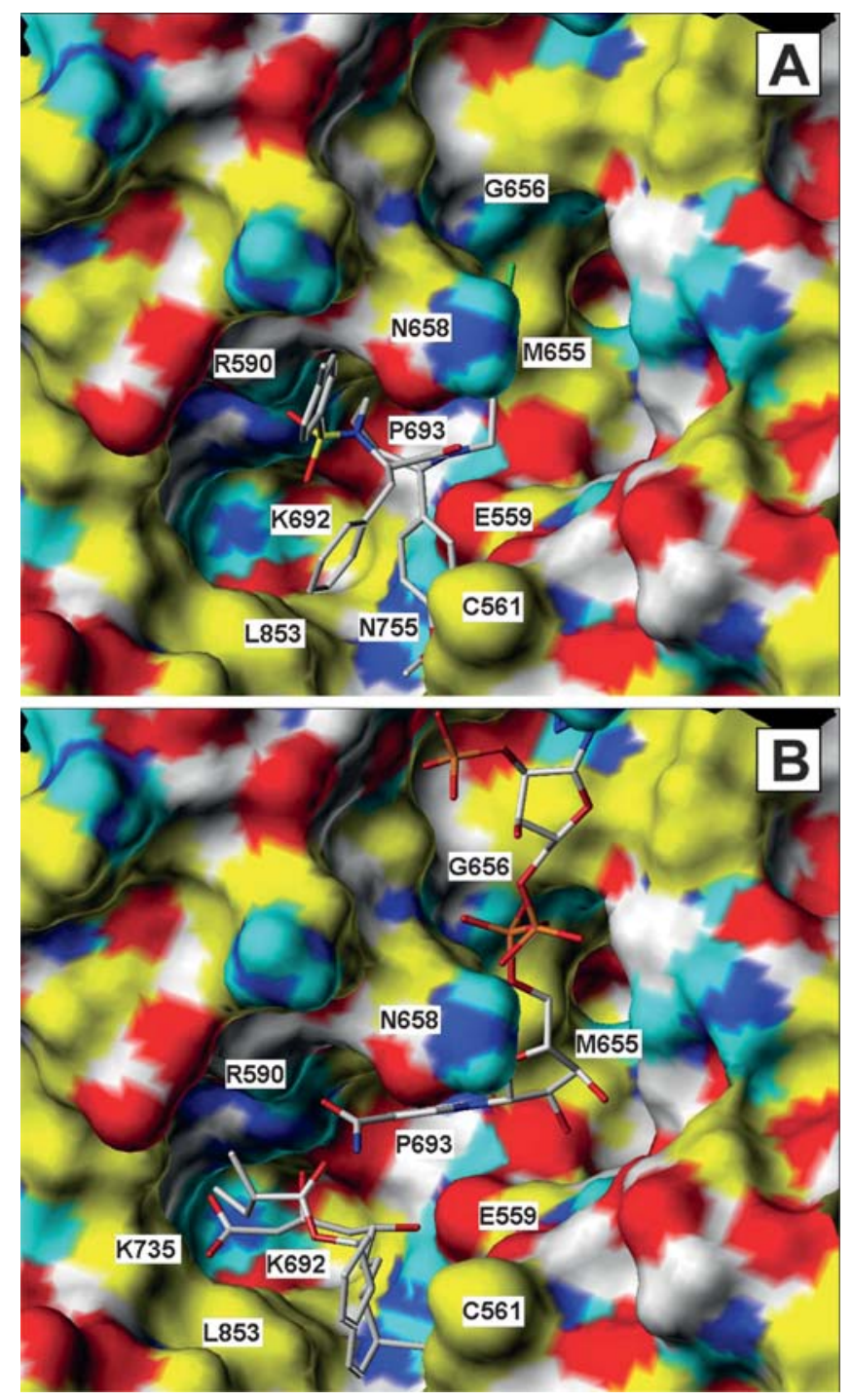

Figure 6. Bound conformers of ligands interacting with the substrate binding sites of HMG-CoA reductase, including (A) the docked conformer of DL-IID4, and (B) crystallographically resolved positions of mevastatin (lower left) and $\mathrm{NADP}^{+}$(upper right) as derived by superimposing relevant crystal structures 1HW8 (9) and 1DQ9 (10) onto our receptor model. All ligands are rendered as CPK-colored sticks. The receptor surface is colored as follows: red $=\mathrm{O}$, blue $=$ polar $\mathrm{N}$, cyan $=$ polar $\mathrm{H}$, white $=$ polar alkyls, and yellow $=$ non-polar alkyls.

substrate block the HMG-CoA reductase-inhibiting activity of $256 \mathrm{nM}$ pravastatin without altering that of $25 \mu \mathrm{M}$ DL-IID7 (Fig. 4), suggesting that MRLs and existing statins may have different mechanisms of enzyme interaction and inhibition. When tested together, suboptimal concentrations of synthetic MRLs (10 $\mu \mathrm{M}$ DL-II-D7 or GG-II-G3) and existing statins (64 $\mathrm{nM}$ pravastatin or simvastatin, sodium salt) have additive inhibitory effects on HMG-CoA reductase activity (Fig. 5). Preliminary molecular docking studies with MRLbased inhibitors indicate that these ligands fit sterically well into the HMG-CoA reductase statin-binding receptor model (Fig. 6). Four of our MRL-based inhibitors (DL-II-D4, GGII-G7, GG-II-G3, DL-II-D7) were docked in the HMG-CoA reductase receptor model via Surflex using default settings and the protomol file defined in Materials and methods, the strength of their interaction being in agreement with their 
Table I. Antitumor and statin-like effects of synthetic MRLs: ranking according to magnitude of HMG-CoA reductase inhibition.

\begin{tabular}{|c|c|c|c|}
\hline Ranking & $\begin{array}{l}\text { Compounds } \\
\text { (code No.) }\end{array}$ & $\begin{array}{l}\text { Specific activity } \\
\text { of HMG-CoA } \\
\text { reductase }^{\mathrm{a}} \\
(\% \text { of control })^{\mathrm{b}}\end{array}$ & $\begin{array}{c}\text { Antiproliferative } \\
\text { activity in L1210 } \\
\text { cells at day } 4^{\mathrm{c}} \\
\mathrm{IC}_{50} \text { values }(\mu \mathrm{M})^{\mathrm{d}}\end{array}$ \\
\hline 1. & DL-II-D7 & 32.3 & $2.30 \pm 0.17$ \\
\hline 2. & GG-II-G3 & 43.4 & $1.43 \pm 0.07$ \\
\hline 3. & GG-II-G7 & 52.6 & $1.48 \pm 0.11$ \\
\hline 4. & GG-II-Ala29 & 54.4 & $1.19 \pm 0.08$ \\
\hline 5. & DL-II-D4 & 64.4 & $1.54 \pm 0.13$ \\
\hline 6. & NB-IX-Gly27 & 66.6 & $2.13 \pm 0.08$ \\
\hline 7. & NB-IX-Gly19 & 70.2 & $4.38 \pm 0.28$ \\
\hline 8. & GG-II-G4 & 73.1 & $2.67 \pm 0.20$ \\
\hline 9. & NB-IX-059-N7 & 76.1 & $2.55 \pm 0.16$ \\
\hline 10. & NB-IX-Gly24 & 76.4 & $3.74 \pm 0.20$ \\
\hline
\end{tabular}

${ }^{a}$ Comparison of the abilities of synthetic MRLs to directly inhibit the catalytic activity of HMG-CoA reductase when tested at $10 \mu \mathrm{M}$ in a cell-free assay in vitro. The concentration of the purified human HMG-CoA reductase stock solution was $0.85 \mathrm{mg}$ protein/ml, spectrophotometric time-scans were conducted over $640 \mathrm{sec}$, and the rates of NADPH consumed were calculated from the decrease in

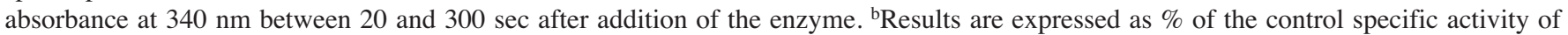
the enzyme in the absence of drugs $(0.600528 \pm 0.039523 \mu \mathrm{mole}$ of NADPH oxidized $/ \mathrm{min} / \mathrm{mg}$ protein, $100 \pm 6.6 \%)$. ${ }^{\mathrm{c} C o n c e n t r a t i o n s}$ of MRLs required to inhibit by $50 \%$ ( $\mathrm{IC}_{50}$ values) the metabolic activity of L1210 leukemic cells, using the MTS:PMS assay after 4 days of culture in vitro. $\mathrm{IC}_{50}$ values $(\mu \mathrm{M})$ were calculated from linear regression of the slopes of the log-transformed concentration-survival curves. ${ }^{\mathrm{d}}$ Means $\pm \mathrm{SD}(\mathrm{n}=3)$.

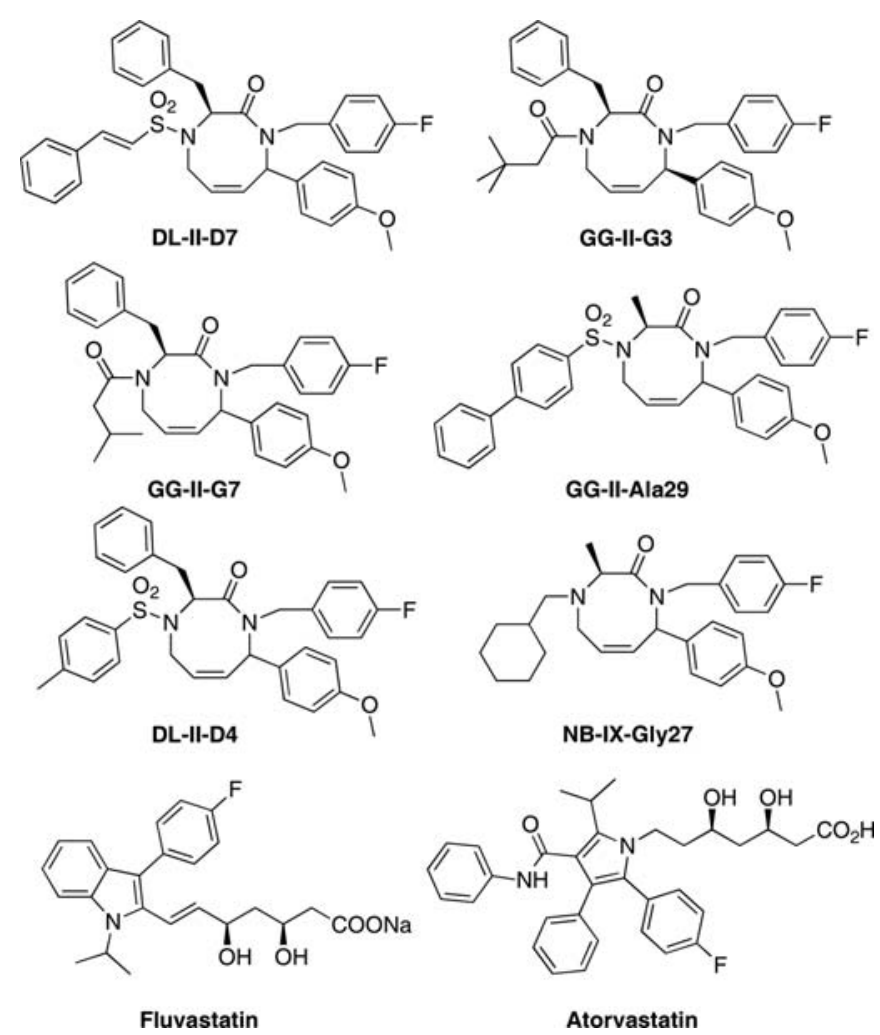

Figure 7. Chemical structure of 6 novel HMG-CoA reductase inhibitors that inhibit tumor cell proliferation. The structure of 2 clinically useful statins is shown for the sake of comparison. activity ranking in the HMG-CoA reductase screening assay (Fig. 2). The bound conformer of DL-II-D4 in the presence of the HMG-CoA reductase statin-binding receptor is rendered in Fig. 6. The parafluorobenzyl group on DL-II-D4 is positioned well to protrude through a channel delimited by the Glu 559, Asn 658 and Pro 693 side chains, and into a broader pocket where the aryl group can interact with the Met 655 side chain (Fig. 6A). As seen in Fig. 6B, this channel has been crystallographically observed to house the pyridinium moiety on $\mathrm{NADP}^{+}(16)$, and the area around Met 655 hosts the $\mathrm{NADP}^{+}$ribosyl group. As is further seen from Fig. 6B, crystallographically characterized statins such as mevastatin (15) do not have functional groups that occupy this region.

Inhibition of tumor cell proliferation. Because statin drugs that block the mevalonate pathway (19) induce pleiotropic effects (20-22), including antitumor activity (23-26), it was of interest to assess and compare the antiproliferative activities of HMG-CoA reductase-inhibiting MRLs to those of existing statins, and determine whether the ability of MRL structures to inhibit HMG-CoA reductase activity was linked to their effectiveness as inhibitor of tumor cell proliferation. Interestingly, all HMG-CoA reductase-inhibiting MRL structures inhibit the mitochondrial ability of L1210 leukemia cells to metabolize the MTS:PMS reagent at day 4 (Fig. 7 and Table I) and the magnitude of their antitumor activity in the low $\mu \mathrm{M}$ range is somewhat greater than that of existing statins. Indeed, the concentration-dependent inhibitions of 


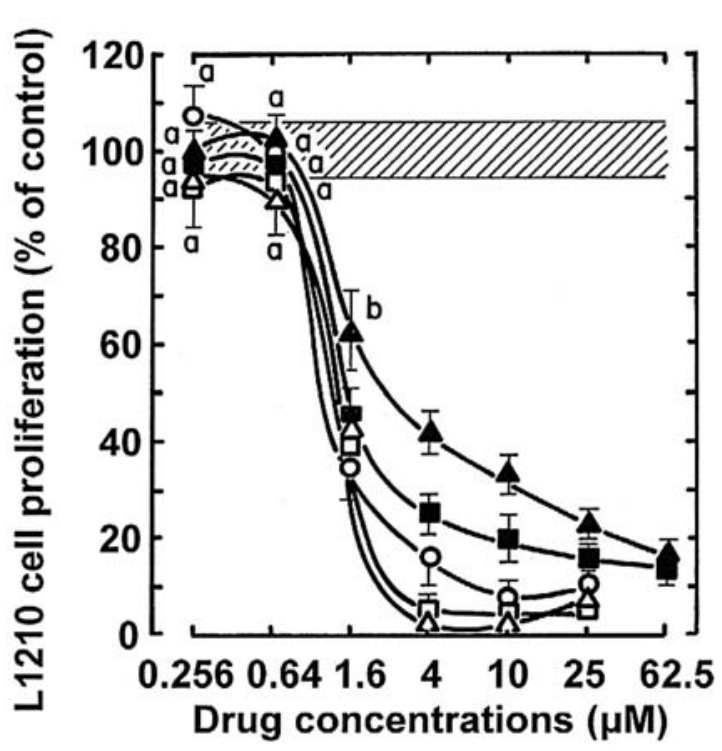

Figure 8. Comparison of the abilities of serial concentrations (logarithmic

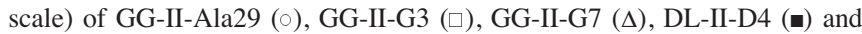
DL-II-D7 (ム) to inhibit the metabolic activity of L1210 tumor cells at day 4 in vitro. Cell proliferation results are expressed as \% of the net absorbance of MTS/formazan after bioreduction by vehicle-treated control cells after 4 days in culture $\left(\mathrm{A}_{490 \mathrm{~nm}}=1.373 \pm 0.077,100 \pm 5.6 \%\right.$, striped area $)$. The blank value $\left(\mathrm{A}_{490 \mathrm{~nm}}=0.351\right.$ at day 4$)$ for cell-free culture medium supplemented with MTS:PMS reagent was substracted from the results. Bars, means \pm SD

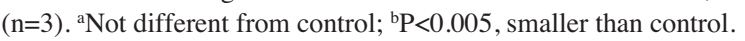

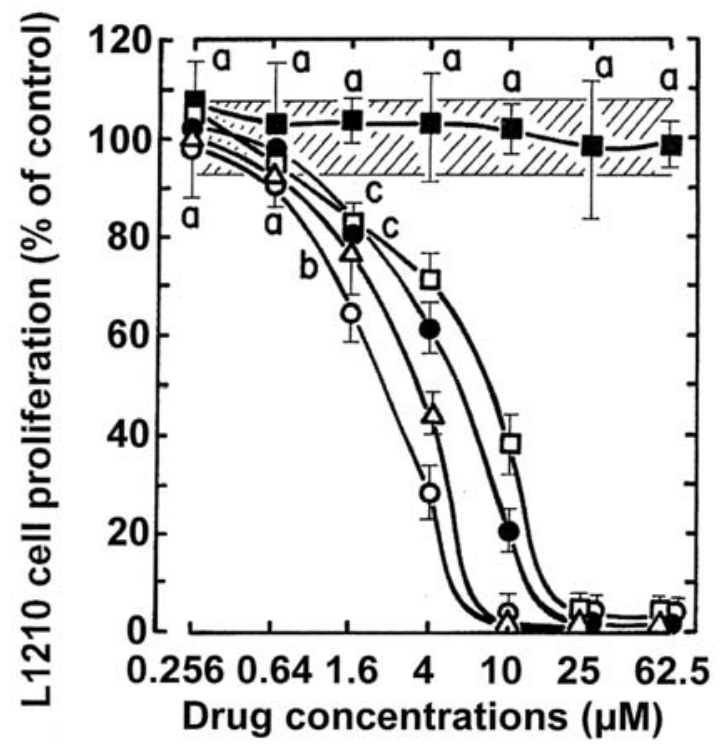

Figure 9. Comparison of the abilities of serial concentrations (logarithmic scale) of fluvastatin $(\bigcirc)$, lovastatin $(\bullet)$, mevastatin $(\square)$, pravastatin $(\bullet)$ and simvastatin $(\Delta)$ to inhibit the metabolic activity of L1210 tumor cells at day 4 in vitro. Cell proliferation results are expressed as \% of the net absorbance of MTS/formazan after bioreduction by vehicle-treated control cells after 4 days in culture $\left(\mathrm{A}_{490 \mathrm{~nm}}=1.138 \pm 0.083,100 \pm 7.3 \%\right.$, striped area $)$. The blank value $\left(\mathrm{A}_{490 \mathrm{~nm}}=0.391\right)$ for cell-free culture medium supplemented with MTS:PMS reagent was substracted from the results. Bars, means \pm SD $(\mathrm{n}=3)$. ${ }^{\mathrm{N}}$ Not different from control; ${ }^{\mathrm{b}} \mathrm{P}<0.05$ and ${ }^{\mathrm{c}} \mathrm{P}<0.025$, smaller than control.

L1210 tumor cell proliferation by the 5 most effective HMGCoA reductase inhibitors, DL-II-D7, GG-II-G3, GG-II-G7,
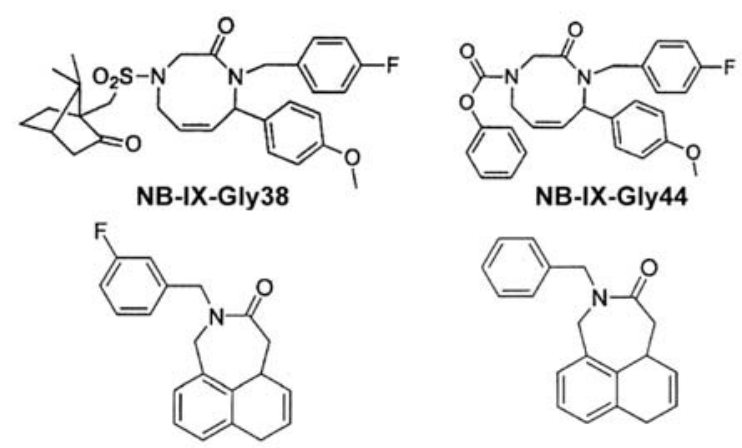

NB-IX-Gly44
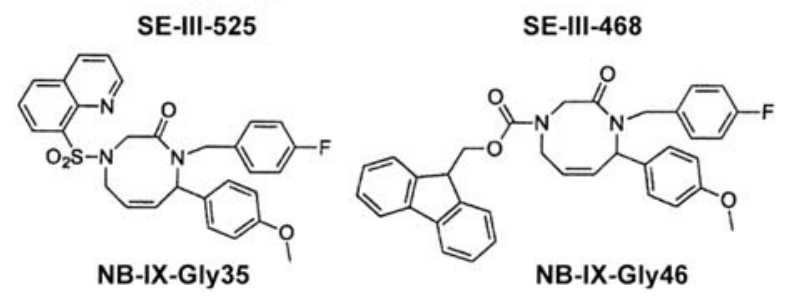

Figure 10. Chemical structures that inhibit tumor cell proliferation but not HMG-CoA reductase activity.

GG-II-Ala29 and DL-II-D4, similarly begin at $1.6 \mu \mathrm{M}$, become maximal at $4-25 \mu \mathrm{M}$, and are characterized by $\mathrm{IC}_{50}$ values of 1.2-2.3 $\mu \mathrm{M}$ (Fig. 8). In contrast, concentrations of pravastatin that totally block HMG-CoA reductase activity (Figs. 1 and 3) are inactive against L1210 tumor cell proliferation (Fig. 9) and mevastatin, lovastatin, simvastatin and fluvastatin inhibit the metabolic activity of L1210 tumor cells at day 4 with concentration-response curves that are characterized by $\mathrm{IC}_{50}$ values of $7.4 \pm 0.3,5.4 \pm 0.3,3.4 \pm 0.2$ and $2.3 \pm 0.1 \mu \mathrm{M}$, respectively (Fig. 9). Sodium salts of mevastatin $\left(\mathrm{IC}_{50}: 5.1 \pm 0.4 \mu \mathrm{M}\right)$, lovastatin $\left(\mathrm{IC}_{50}: 4.3 \pm 0.3 \mu \mathrm{M}\right)$ and simvastatin $\left(\mathrm{IC}_{50}: 2.7 \pm 0.2 \mu \mathrm{M}\right)$ are not significantly more effective against L1210 tumor cell proliferation at day 4 (data not shown). Moreover, several other MRL structures that inhibit L1210 tumor cell proliferation in the 470-800 nM range fail to alter $\mathrm{HMG}-\mathrm{CoA}$ reductase activity when tested at $10 \mu \mathrm{M}$ (Fig. 10 and Table II), suggesting that other molecular targets may be involved in their antitumor action. Different moieties of the MRL framework might be responsible for antiproliferative activity and inhibitory interaction with the HMG-CoA reductase enzyme. Although the correlation between the concentration-dependent inhibitions of HMGCoA reductase activity over $10 \mathrm{~min}$ in the cell-free assay and L1210 tumor cell proliferation over 4 days in culture is unclear for this series of bioactive compounds, GG-II-G3 and DL-II-D7 elicit interesting combinations of statin-like $\left(\mathrm{IC}_{50}\right.$ : 7.4-8.0 $\mu \mathrm{M})$ and anti-tumor $\left(\mathrm{IC}_{50}: 1.4-2.3 \mu \mathrm{M}\right)$ activities.

\section{Discussion}

Human HMG-CoA reductase, the rate-limiting enzyme in cholesterol biosynthesis, is a transmembrane glycoprotein, anchored to the endoplasmic reticulum, that catalyzes the NADPH-dependent 4-electron reduction of HMG-CoA to CoA and mevalonate $(16,27,28)$. The active catalytic site of the cytoplasmic, soluble carboxy-terminal portion of HMGCoA reductase has 3 domains which bind either the HMG 
Table II. Antitumor and statin-like effects of synthetic MRLs: ranking according to magnitude of inhibition of L1210 cell proliferation.

\begin{tabular}{|c|c|c|c|}
\hline Ranking & $\begin{array}{l}\text { Compounds } \\
\text { (code No.) }\end{array}$ & $\begin{array}{l}\text { Specific activity } \\
\text { of HMG-CoA } \\
\text { reductase }^{\mathrm{a}} \\
(\% \text { of control })^{\mathrm{b}}\end{array}$ & $\begin{array}{l}\text { Antiproliferative } \\
\text { activity in } \mathrm{L} 1210 \\
\text { cells at day } 4^{\mathrm{c}} \\
\mathrm{IC}_{50} \text { values }(\mu \mathrm{M})^{\mathrm{d}}\end{array}$ \\
\hline 1. & NB-IX-Gly38 & 104.8 & $0.47 \pm 0.03$ \\
\hline 2. & NB-IX-Gly44 & 102.2 & $0.64 \pm 0.04$ \\
\hline 3. & SE-III-525 & 101.1 & $0.68 \pm 0.04$ \\
\hline 4. & SE-III-468 & 102.9 & $0.80 \pm 0.05$ \\
\hline 5. & NB-IX-Gly35 & 98.5 & $1.09 \pm 0.09$ \\
\hline 6. & NB-IX-Gly46 & 104.4 & $1.14 \pm 0.09$ \\
\hline 7. & GG-II-Ala31 & 85.9 & $1.16 \pm 0.06$ \\
\hline
\end{tabular}

${ }^{a}$ Comparison of the abilities of synthetic MRLs to directly inhibit the catalytic activity of HMG-CoA reductase when tested at $10 \mu \mathrm{M}$ in a cell-free assay in vitro. ${ }^{\mathrm{b}}$ The conditions of the experiments and the determination of the results, expressed as $\%$ of the control specific activity of the enzyme ( $\mu$ mole of NADPH oxidized $/ \mathrm{min} / \mathrm{mg}$ protein) in the absence of drugs, were identical to those of Table I. ${ }^{c}$ Concentrations of MRLs required to inhibit by $50 \%$ ( $\mathrm{IC}_{50}$ values) the metabolic activity of $\mathrm{L} 1210$ leukemic cells, using the MTS:PMS assay after 4 days of culture in vitro. ${ }^{\mathrm{d}}$ Means $\pm \mathrm{SD}(\mathrm{n}=3)$.

portion of HMG-CoA, CoA, or NADPH $(19,29)$. Since certain MRLs, structurally unrelated to existing statins, inhibit the catalytic activity of purified human HMG-CoA reductase in a cell-free assay, these bioactive compounds might represent a novel class of $\mathrm{HMG}-\mathrm{CoA}$ reductase inhibitors that can directly interact with this enzyme to block the mevalonate pathway and prevent hypercholesterolemia. The crystal structures of the catalytic portion of human HMG-CoA reductase bound to existing statins reveal that, despite their structural diversity, all inhibitors extend into the narrow HMG-binding pocket but not into the elongated NADPH binding site. Current natural type 1 and synthetic type 2 statins, therefore, are all competitive inhibitors that interact at the HMG-CoA binding site of HMG-CoA reductase because they share a group that resembles the HMG portion of HMGCoA, thus sterically preventing the substrate from binding $(15,30)$. Active statins are administered as salts of carboxylic acids. The lactone forms of some statins are inactive prodrugs that must undergo a ring-opening reaction to be enzymatically hydrolyzed to their active hydroxyl-acid forms by carboxy-esterases in vivo (31). The fact that, in the present assay, there are 133- to 183-fold increases in the potencies of lovastatin, mevastatin and simvastatin when these drugs are tested as sodium salts confirms that current statins need to be trans-formed into active dihydroxy open acid forms to express their full HMG-CoA reductase-inhibiting potential in a cellfree system.

Preliminary computational docking suggests that MRLbased inhibitors fit sterically well into the HMG-CoA reductase statin-binding receptor model. However, while the HMGCoA reductase-inhibiting activity of pravastatin is normally overcome by HMG-CoA but not NADPH, neither increasing concentrations of NADPH nor HMG-CoA substrates can reverse the inhibiting effect of DL-II-D7, suggesting that MRLs might use different mechanisms for interacting with, disrupting and inhibiting HMG-CoA reductase. In contrast to mevastatin, DL-II-D4 has a functional group that extends into the narrow channel housing the pyridinium moiety on $\mathrm{NADP}^{+}$, suggesting that the binding interaction by which MRLs inhibit the catalytic activity of the HMG-CoA reductase enzyme might be different from that of conventional statins. Such MRL interference with NADPH, however, might be irreversible and not circumvented by increasing concentration of this substrate. The independence of pravastatin and DL-IID7 relative to NADPH concentration might arise from different mechanisms: perhaps pravastatin is non-competitive relative to NADPH, whereas DL-II-D7 and other analogs successfully out-compete NADPH at all of the concentrations studied. Various lipophilic groups with no substrate homology have also been suggested to play a role in determining the mechanism of binding of HMG-CoA reductase inhibitors (32). Moreover, the additivity of the HMG-CoA reductaseinhibiting effects of DL-II-D7 or GG-II-G3 and pravastatin or simvastatin (sodium salts) suggests that, even though they are less potent, novel MRL inhibitors of HMG-CoA reductase with a different mechanism of action might be valuable to complement or supplement the clinical effects of the current statins. Since existing statins share rigid, hydrophobic groups that are covalently linked to the conserved HMG-like moiety, the chemical functionality that enables MRL structures to interact with and inhibit the active site of HMG-CoA reductase must be elucidated. The kinetics of such HMG-CoA reductase inhibition by MRLs remain to be characterized but, based on the present results, are unlikely to be similar to those of existing statins, which, because of their shared HMG-CoA-like moiety, are competitive with respect to HMG-CoA and non-competitive when NADPH is varied (27). It is worth noting that while DL-II-D4 fits sterically well into the receptor, it can not yet be considered to be optimized in terms of electrostatic compatibility. The strength of the interaction is likely derived from a complementary lipophilic interaction between the ligand benzyl group and 
the hydrophobic pocket consisting of Leu 853 and the hydrophobic portion of the Lys 692 side chain, plus a significant H-bond formed between the ligand sulfonyl and the Arg 590 side chain. There may also be an oblique interaction between the lactam carbonyl and the Asn 658 amide proton, modest lipophilic complementarity between the anisole group and the Cys 561 side chain, and a likely H-bond between the anisole oxygen and the Asn 755 side chain amide proton. The fluorobenzyl group adjacent to the sulfonyl occupies a pocket that affords a favorable lipophilic interaction between the aromatic ring and the Met 655 side chain, plus an opportunity for a marginal $\mathrm{H}$-bond between the fluorine and the Gly 656 backbone amide proton. Finally, the toluenyl group appears to occupy a fairly solvent-exposed area that might be somewhat more favorable for a somewhat more polar species.

As certain MRLs are slightly more potent inhibitors of L1210 tumor cell proliferation than existing statins, these compounds might represent a novel synthetic class of bifunctional drugs with an interesting combination of antitumor and statin-like activities. But the relationship between the ability of MRLs to directly inhibit HMG-CoA reductase activity within $10 \mathrm{~min}$ in a cell-free assay and their effectiveness against L1210 tumor cell proliferation after 4 days in culture is difficult to ascertain because of the different nature of these systems. The inhibition of cellular HMG-CoA reductase activity by MRLs would have to be demonstrated to determine whether the disruption of the mevalonate pathway is related to their antitumor action. In the present study, sodium salts of existing statins inhibit the activity of the purified HMG-CoA reductase enzyme in the $\mathrm{nM}$ range in the cell-free assay but require $\mu \mathrm{M}$ treatments to prevent L1210 tumor cells from growing in culture, and the classic HMG-CoA reductase inhibitor pravastatin (sodium salt) is even devoid of antiproliferative activity. Conversely, the most potent antitumor MRLs of the series synthesized so far are effective against L1210 tumor cell proliferation in the $\mathrm{nM}$ range at day 4 but are totally ineffective in the HMG-CoA reductase activity screening assay at $10 \mu \mathrm{M}$. Such apparent discrepancies suggest that HMG-CoA reductase inhibition might only play a marginal role in the antiproliferative action of various antineoplastic therapeutics. Hence, the HMG-CoA reductaseinhibiting potential of MRLs is unlikely to be required for their antitumor activity and the structural functionalities responsible for their interaction with the catalytic site of the HMG-CoA reductase enzyme and for modulating their antitumor potency are likely to be different.

There are at least a few superficial but possibly significant structural correlations between the known statins and the library of seven- and eight-membered ring compounds evaluated for HMG-CoA reductase inhibitory activity in this study. For example, all of the MRLs, along with the two topologically distinct seven-membered tricyclic structures, feature aromatic- and olefinic-rich architectures that render them substantially lipophilic, much like the statins. Moreover, virtually all of the tested compounds possess an electronpoor, fluoro-substituted aromatic moiety, as do the indolecontaining fluvastatin and pyrrole-based atorvastatin (Fig. 7). However, the substantially lower HMG-CoA reductase inhibitory activity exhibited by all of the MRLs may be rationalized by their absence of the critical stereochemically defined 1,3-diol carboxylate motif that is found in all of the clinically useful statins (or their corresponding pro-drug lactones). Alternatively, the MRLs may exert their activity by a completely different mechanism. It is interesting to note that each of the MRLs possess a somewhat flattened eightmembered unsaturated lactam core with aromatic substituents oriented in several directions. In this respect, the nitrogencontaining MRLs most closely resemble atorvastatin which features a similarly planar and multi-substituted pyrrole core (Fig. 7). Incorporating 1,3-diol carboxylate units at various positions in the MRL scaffold offers an attractive strategy for addressing this issue in the next-generation of compounds.

Mevalonate is a crucial intermediate for the downstream production of cholesterol as well as non-sterol isoprenoid compounds, such as farnesyl pyrophosphate (FPP) and geranylgeranyl pyrophosphate (GGPP), which are vital for the posttranslational modification (isoprenylation) required to anchor oncogenic proteins to the inner surface of the plasma membrane and activate their function (19,33-36). High levels of mevalonate-derived isoprenoids implicated in oncogene activation and tumorigenesis, such as FPP and GGPP, have been demonstrated in malignancy $(37,38)$. Since mevalonatederived cholesterol and non-sterol products may be required to sustain tumor growth, many hyperplastic neoplastic cells may have a greater requirement than their normal counterparts for the synthesis of cholesterol and prenyl pyrophosphate intermediates that may be fulfilled by an increased HMGCoA reductase activity (39-42). Statins, therefore, have been suggested to exert their anticancer effects by inhibiting the formation of mevalonate-derived farnesyl and geranylgeranyl groups required for the isoprenylation of oncogenic proteins as a downstream effect of HMG-CoA reductase inhibition $(23,26,43)$. The ability of statins to arrest cell cycle progression at $\mathrm{G}_{1}$, increase p21 ${ }^{\mathrm{WAF} 1}$ and p27 expression, decrease cdk 2associated kinase activity, and prevent the phosphorylation of histone- $\mathrm{H} 1$ and $\mathrm{Rb}$ is reversed by mevalonate, suggesting that mis-sing components of the $\mathrm{HMG}-\mathrm{CoA}$ reductase pathway are responsible for cell cycle arrest by statins $(19,44-47)$. Statins also increase the expression of Bax and decrease that of Bcl-2 to induce apoptosis in tumor cells and these effects can be reversed by mevalonate and GGPP but not FPP, suggesting that inhibition of geranylgeranylation mediates statin-induced apoptosis $(20,23,42,47,48)$.

Although the ability of DL-II-D7, GG-II-G3, GG-II-G7, GG-II-Ala29 and DL-II-D4 to inhibit the HMG-CoA reductase-controlled production of mevalonate metabolites required to sustain tumor cell growth might play a partial role in their mechanism of antitumor action, it is speculated that the lead bioactive MRLs might target other more important molecular events, which have yet to be defined, to exert their antitumor activity. For instance, promising antitumor MRLs lacking HMG-CoA reductase-inhibiting activity like NB-IXGly38 and NB-IX-Gly44, which inhibit macromolecule syntheses and stimulate the formation of binucleated cells and micronuclei, might prevent the uptake or incorporation of precursors into DNA, RNA and proteins, and indirectly cause chromosomal damage or missegregation to enhance mitotic abnormality and block cytokinesis. More effective MRL derivatives with bioactivity in the low $\mathrm{nM}$ range would have to be discovered to explore structure-activity relationships, 
identify their molecular targets, elucidate their mechanism of action and assess their preclinical potential for eventual development as antitumor and statin-like drugs.

\section{Acknowledgements}

This study was supported by grants from the Howard Hughes Medical Institute (Biological Sciences Education Grant) and Kansas State University (Innovative Research Award from the Terry C. Johnson Center for Basic Cancer Research and Research Seed Grant Award from the Biology Research and Instruction Enhancement Fund Program). We also acknowledge support of this work by the National Institutes of Health: Grant R01 GM069711 (to KRB) and University of Kansas Center of Excellence in Chemical Methodologies and Library Development (KU-CMLD), Grant P50 GM069663.

\section{References}

1. Tapiolas DM, Roman M, Fenical W, Stout TJ and Clardy J: Octalactins A and B: cytotoxic eight-membered-ring lactones from a marine bacterium, Streptomyces sp. J Am Chem Soc 113: 4682-4683, 1991

2. Perchellet JP, Perchellet EM, Newell SW, Freeman JA, Ladesich JB, Jeong Y, Sato N and Buszek KR: Antitumor activity of novel octalactin A analogs in murine leukemia cells in vitro. Anticancer Res 18: 97-106, 1998.

3. Brown N, Xie B, Markina N, VenderVelde D, Perchellet JP, Perchellet EM, Crow KR and Buszek KR: Synthesis of a natural product-inspired eight-membered ring lactam library via ringclosing metathesis. Bioorg Med Chem Lett 18: 4876-4679, 2008.

4. Brown N, Gao G, Minatoya M, Xie B, VanderVelde D, Lushington GH, Perchellet JP, Perchellet EM, Crow KR and Buszek KR: Design and synthesis of medium-ring lactam libraries inspired by octalactin A. A convergent-divergent approach. J Comb Chem 10: 628-631, 2008.

5. Buszek KR: First intramolecular benzyne Diels-Alder reaction with an acyclic diene. Unusual effect of diene geometry on the course of the reaction. Tetrahedron Lett 36: 9125-9128, 1995.

6. Buszek KR and Bixby DL: Total synthesis of pseudopterosin A and E aglycon. Tetrahedron Lett 36: 9129-9132, 1995.

7. Buszek KR, Luo D, Kondrashov M, Brown N and VanderVelde D: Indole-derived arynes and their Diels-Alder reactivity with furans. Org Lett 9: 4135-4137, 2007.

8. Buszek KR, Brown N and Luo D: Concise total Synthesis of $( \pm)$-cis-trikentrin A and $( \pm)$-herbindole A via intermolecular indole aryne cycloaddition. Org Lett 11: 201-204, 2009.

9. Brown N, Luo D, VanderVelde D, Yang S, Brassfield A and Buszek KR: Regioselective Diels- Alder cycloadditions and other reactions of 4,5-, 5,6-, and 6,7-indole arynes. Tetrahedron Lett 50: 63-65, 2009.

10. Hayes ME, Shinokubo H and Danheiser RL: Intramolecular [4+2] cycloadditions of benzynes with conjugated enynes, arenynes, and dienes. Org Lett 7: 3917-3920, 2005.

11. Cory AH, Owen JC, Barltrop JA and Cory JG: Use of an aqueous soluble tetrazolium/formazan assay for cell growth assays in culture. Cancer Commun 3: 207-212, 1991.

12. Park WKC, Kennedy RM, Larsen SD, Miller S, Roth BD, Song Y, Steinbaugh BA, Sun K, Tait BD, Kowala MC, Trivedi BK, Auerbach B, Askew V, Dillon L, Hanselman JC, Lin Z, Lu GH, Robertson A and Sekerke C: Hepatoselectivity of statins: design and synthesis of 4-sulfamoyl pyrroles as HMG-CoA reductase inhibitors. Bioorg Med Chem Lett 18: 1151-1156, 2008.

13. UNITY 4.4.3 (2007): The Tripos Associates, St. Louis MO, 2007.

14. SYBYL 8.0 (2007): The Tripos Associates, St. Louis MO, 2007.

15. Istvan ES and Deisenhofer J: Structural mechanism for statin inhibition of HMG-CoA reductase. Science 292: 1160-1164, 2001.

16. Istvan ES, Palnitkar M, Buchanan SK and Deisenhofer J: Crystal structure of the catalytic portion of human HMG-CoA reductase: insights into regulation of activity and analysis. EMBO J 19: 819- 830, 2000.
17. Sarver RW, Bills E, Bolton G, Bratton LD, Caspers NL, Dunbar JB, Harris MS, Hutchings RH, Kennedy RM, Larsen SD, Pavlovsky A, Pfefferkorn JA and Bainbridge G: Thermodynamic and structure guided design of statin based inhibitors of 3-hydroxy-3-methylglutaryl coenzyme a reductase. J Med Chem 51: 3804-3813, 2008.

18. Jain AN: Surflex: fully automatic flexible molecular docking using a molecular similarity-based search engine. J Med Chem 46: 499-511, 2003.

19. Goldstein JL and Brown MS: Regulation of the mevalonate pathway. Nature 343: 425-430, 1990.

20. Demierre MF, Higgins PDR, Gruber SB, Hawk E and Lippman SM: Statins and cancer prevention. Nat Rev Cancer 5: 930-942, 2005.

21. Hawk E and Viner JL: Statins and cancer-beyond the 'one drug, one disease' model. N Engl J Med 352: 2238-2239, 2005.

22. Paraskevas KI, Tzovaras AA, Briana DD and Mikhailidis DP: Emerging indications for statins: a pluripotent family of agents with several potential applications. Curr Pharm Des 13: 3622-3636, 2007.

23. Wong WW, Dimitroulakos J, Minden MD and Penn LZ: HMGCoA reductase inhibitors and the malignant cell: the statin family of drugs as triggers of tumor-specific apoptosis. Leukemia 16: 508- 519, 2002.

24. Chan KK, Oza AM and Siu LL: The statins as anticancer agents. Clin Cancer Res 9: 10-19, 2003.

25. Graaf MR, Richel DJ, van Noorden CJ and Guchelaar HJ: Effects of statins and farnesyltransferase inhibitors on the development and progression of cancer. Cancer Treat Rev 30: 609-641, 2004.

26. Fritz G: HMG-CoA reductase inhibitors (statins) as anticancer drugs (Review). Int J Oncol 27: 1401-1409, 2005.

27. Holdgate GA, Ward WHJ and McTaggart F: Molecular mechanism for inhibition of 3-hydroxy-3- methylglutaryl CoA (HMG-CoA) reductase by rosuvastatin. Biochem Soc Trans 31: 528-531, 2003.

28. Friesen JA and Rodwell VW: The 3-hydroxy-3-methylglutaryl coenzyme-A (HMG-CoA) reductases. Genome Biol 5: 248, Epub Nov 1, 2004.

29. Istvan ES and Deisenhofer J: The structure of the catalytic portion of human HMG-CoA reductase. Biochim Biophys Acta 1529: 9-18, 2000.

30. Endo A, Kuroda M and Tanzawa K: Competitive inhibition of 3-hydroxy-3-methylglutaryl coenzyme A reductase by ML236A and ML-236B fungal metabolites, having hypocholesterolemic activity. FEBS Lett 72: 323-326, 1976.

31. Alberts AW, Chen J, Kuron G, Hunt V, Huff J, Hoffman C, Rothrock J, Lopez M, Joshua H, Harris E, Patchett A, Monaghan R, Currie S, Stapley E, Albers-Schonberg G, Hensens O, Hirshfield J, Hoogsteen K, Liesch J and Springer J: Mevinolin: a highly potent competitive inhibitor of hydroxymethylglutaryl-coenzyme A reductase and a cholesterollowering agent. Proc Natl Acad Sci USA 77: 3957-3961, 1980.

32. Louis-Flamberg P, Peishoff CE, Bryan DL, Leber J, Elliott JD, Metcalf BW and Mayer RJ: Slow binding inhibition of 3hydroxy-3-methylglutaryl-coenzyme A reductase. Biochemistry 29: 4115- 4120, 1990

33. Repko EM and Maltese WA: Post-translational isoprenylation of cellular proteins is altered in response to mevalonate availability. J Biol Chem 264: 9945-9952, 1989.

34. Casey PJ, Solski PA, Der CJ and Buss JE: p21ras is modified by a farnesyl isoprenoid. Proc Natl Acad Sci USA 86: 8323-8327, 1989.

35. Maltese WA: Posttranslational modification of proteins by isoprenoids in mammalian cells. FASEB J 4: 3319-3328, 1990.

36. Sinensky M: Recent advances in the study of prenylated proteins. Biochim Biophys Acta 1484: 93-106, 2000.

37. Siperstein MD: Role of cholesterogenesis and isoprenoid synthesis in DNA replication and cell growth. J Lipid Res 25: 1462-1468, 1984.

38. Caruso MG and Notarnicola M: Biochemical changes of mevalonate pathway in human colorectal cancer. Anticancer Res 25: 3393-3398, 2005.

39. Rudling MJ, Angelin B, Peterson CO and Collins VP: Low density lipoprotein receptor activity in human intracranial tumors and its relation to the cholesterol requirement. Cancer Res 50: 483- 487, 1990.

40. Bennis F, Favre G, Le Gaillard F and Soula G: Importance of mevalonate-derived products in the control of HMG-CoA reductase activity and growth of human lung adenocarcinoma cell line A549. Int J Cancer 55: 640-645, 1993. 
41. Hentosh P, Yuh SH, Elson CE and Peffley DM: Sterolindependent regulation of 3-hydroxy-3- methylglutaryl coenzyme A reductase in tumor cells. Mol Carcinog 32: 154-166, 2001.

42. Notarnicola M, Messa C, Pricci M, Guerra V, Altomare DF, Montemurro S and Caruso MG: Up- regulation of 3-hydroxy-3methylglutaryl coenzyme A reductase activity in left-sided human colon cancer. Anticancer Res 24: 3837-3842, 2004.

43. Schafer WR, Kim R, Sterne R, Thorner J, Kim SH and Rine J: Genetic and pharmacological suppression of oncogenic mutations in ras genes of yeast and humans. Science 245: 379-385, 1989.

44. Jakobisiak M, Bruno S, Skierski JS and Darzynkiewicz Z: Cell cycle-specific effects of lovastatin. Proc Natl Acad Sci USA 88: 3628-3632, 1991.

45. Keyomarsi K, Sandoval L, Band V and Pardee AB: Synchronization of tumor and normal cells from G1 to multiple cell cycles by lovastatin. Cancer Res 51: 3602-3609, 1991.
46. Gray-Bablin J, Rao S and Keyomarsi K: Lovastatin induction of cyclin-dependent kinase inhibitors in human breast cells occurs in a cell cycle-independent fashion. Cancer Res 57: 604-609, 1997.

47. Lee SJ, Ha MJ, Lee J, Nguyen PM, Choi YH, Pirnia F, Kang W-K, Wang X-F, Kim S-J and Trepel JB: Inhibition of the 3-hydroxy3-methylglutaryl-coenzyme A reductase pathway induces p53independent transcriptional regulation of p21WAF1/CIP1 in human prostate carcinoma cells. J Biol Chem 273: 10618-10623, 1998.

48. Agarwal B, Bhendwal S, Halmos B, Moss SF, Ramey WG and Holt PR: Lovastatin augments apoptosis induced by chemotherapeutic agents in colon cancer cells. Clin Cancer Res 5: 2223-2229, 1999. 